\title{
Standardization of Fertilizers in Banana (Musa paradiscica) for Better Growth and Yield
}

\author{
Mamta Kumari ${ }^{1 *}$ and R.N. Singh ${ }^{2}$ \\ ${ }^{1}$ Krishi Vigyaan Kendra Sabour Bhagalpur-813210, India \\ ${ }^{2}$ Bihar Agricultural University, India \\ *Corresponding author
}

\section{A B S T R A C T}

Banana (Musa paradiscica $\mathrm{L}$ ) is a very important fruit crop. It ranks second in the table of importance after mango. It can be grown in tropical and sub-tropical regions. It is grown for its commercial importance since it has both medicinal properties and nutritive value.

\begin{tabular}{|c|}
\hline Keywords \\
\hline $\begin{array}{l}\text { Tropical, } \\
\text { Subtropical, } \\
\text { Community, } \\
\text { Qualitative } \\
\text { property, } \\
\text { Standardization }\end{array}$ \\
\hline Article Info \\
\hline $\begin{array}{l}\text { Accepted: } \\
20 \text { June } 2019 \\
\text { Available Online: } \\
\text { 10 July } 2019\end{array}$ \\
\hline
\end{tabular}
community. Keeping in view its high commercial importance, an on farm trial was designed for standardization of fertilizer in banana for quality yield. This trial was conducted during FY 2014-15 and 2015- 16 in banana growing areas of Bhagalpur district. Banana is a heavy feeder crop that needs management round the year. In utilization of nutrient, it is very critical. Like in the initial stage of growth; higher dose of nitrogen can be used. As far as potash is concerned, its dose can be increased with the age of plants towards flowering. Last dose of fertilizer is applied at the time of blooming of flower. Plant in it, has an inbuilt phosphorus management property. The trial was conducted with treatments T1 T2 and T3. Out of these treatments, T1 performance was the best (that is $400 \mathrm{gof}$ urea $+150 \mathrm{~g}$ of DAP $+700 \mathrm{~g}$ of Muriate of potash) (banana cultivation guide, 2013). It was applied on different date of sowing. Yield performance was found best with yield of 67.89 tonnes per hectare. Regarding BC Ratio same pattern was found, it was highest 3.30.The result was supported by other parameters like plant height, stem girth weight of banana, weight of bunch. Worst result was found in T3 that is $400 \mathrm{~g}$ urea, 200g DAP and $150 \mathrm{~g}$ MOP per pseudostem. Yield obtained in this treatment was 59.74 tonnes per hectare. Whereas in farmers practice it was lowest with 47.52 tonnes yield with BC Ratio 2.50.

\section{Introduction}

Banana is an important member of the family Musacae with botanical name Musa paradiscica. The scientific name of banana is Musa acuminita, Musa balbisiana or, hybrids of Musa acuminita and balbisiana, depending of their genomic constitution. The banana is not a tree, but a high herb that can attain a height of fifteen feet. It is a vigorously growing monocotyledonous herbaceous plant. The banana plants have wide diversity among the genus related to plant height, fruit size, their morphology, fruit quality and disease and insect resistance. Most banana plants have a sweet flavour when ripe; exceptions to this are vegetable banana which are plantains. There is a wide range of variety existing in banana. 
They are Robusta, Red Banana, Poovan, Nendran, GrandNaine, Rasthali etc. Banana is the second most important fruit crop in India, next to mango. Its round year availability, varietal range, taste, nutritive value and medicinal properties make it the favourite fruit among all classes of the society. Banana is very popular due to its low price and high nutritive value. It is consumed as either fresh or cooked. Banana is a rich source of carbohydrate, vitamins- particularly Vitamin B. Potassium, phosphorous, calcium, magnesium are also present in appreciable amount. The fruits are free of fat and cholesterol and are easily digestible. They are rich sources of energy. Banana powders are considered as the first baby-food. A patient suffering from high blood-pressure, arthritis, ulcers, gastroenteritis and kidney disorders are advised to consume banana. There is a variety of processed products like chips, banana puree, jam, jelly, juice, wine and sweets which are prepared from banana. Banana flowers are nice and popular vegetables. Banana fibres are used to make bags, pots, wall hangings, ropes and good quality papers. Banana leaves are used to prepare healthy and hygienic eating plates. It also has a decent export potential. Through scientific approach, the cultivation of the crop is an economically viable enterprise, leading to increase in quality production, productivity, improvement in quality and early crop maturity commanding premium price in the market.

Banana has its importance from the ancient times. In Sanskrit, it's known as Kadliphalam. A known Hinduism belief is that Lord Vishnu lives in Banana. Banana originated in the humid tropical regions of South-East Asia, with India being one of its centres of origin. During the seventeenth century AD, it spread to Egypt and Africa. At present, banana is being cultivated throughout the warm tropical regions of the world between 30 degrees north and 30degrees south of the Equator.

\section{Area of production}

Banana is grown in about 120 countries. Total annual production is estimated as 29163 thousand metric tonnes of fruits in total area of 858 thousand hectare (horticulture Statistics at a Glance 2017, published by Government of India, Ministry of Agriculture \& Farmers Welfare). India leads the world in banana production with an annual output of about 14.2 million tonnes. Brazil, Ecuador, China, Cost Arica, Mexico, Thailand, Columbia, Indonesia and Philippines are the other major leading producing countries. In India, banana ranks first in the production and third in area among the fruit crops. It accounts for $13 \%$ of total area and $33 \%$ of production of fruits. Production is the highest in Maharashtra (3924.1 thousand tonnes) followed by Tamil Nadu (3533.8 thousand tonnes). Maharashtra has the highest productivity of 65.70 metric tonnes per hectare against the national average of 30.5 tonnes per hectare (NHB, 2017). Gujarat, Andhra Pradesh, Assam, Karnataka and Bihar are the major growing states.

In Bihar, banana is grown under the area of 27.2 thousand hectares with a production of 544.9 thousand metric tonnes (NHB, 2001 \&2002). Major growing districts are Bhagalpur, Vaishali and Hajipur. In Bhagalpur district, the major growing blocks are Kharik, Bihpur, Naugachhia and Gopalpur. Recently, the crop's growth graph has taken a hike in Rangra and Pirpainti block. Banana ranks second in importance (after mangos) in Bhagalpur district, both by area and production. Presently, there are a number of issues which the quality production of banana is facing in the district. For example, floods, diseases and pests appearances and lack for proper use of fertilizers. Due to these shortcomings, banana crops, although being qualified enough with all the best export parameters, are not being able to meet the endpoints. Therefore, realising and keeping in 
view all these significance, Krishi Vigyaan Kendra, Sabour, Bhagalpur conducted an On Farm Trial (OFT). The trials dealt with standardization of fertilizers in banana for quality production. This OFT was conducted during the year of 2014-15 and 2015-16 with the following objectives:

To standardise the best fertility levels for quality production.

Economic production package and best quality produce.

Decrease the cost of cultivation with high profitability.

\section{Materials and Methods}

Krishi Vigyaan Kendra, Sabour, Bhagalpur situated on the bank of Holy River Ganga. There is a vast diverse terrain to work on in this region. This OFT was designed to optimise /standardise the dose of fertilizer of banana. Bhagalpur district has sixteen blocks. Out of these, five blocks have banana as the major crops. These blocks are Kharik, Bihpur, Naugachhia, Gopalpur and Narayanpur with an average area under banana cultivation of 12000 hectares. Bhagalpur district is divided by river Ganga. The nature of the soil is also different in these areas. Two major crops of these areas are litchi and banana. On contrary the growth of litchi is better in acidic soil whereas banana does better in neutral soil. Pre and post soil testing was conducted. Status of soil showed in table 1.

Farmers were selected randomly on the basis of qualification, interest and skill in agriculture sector. They were from Mahadatpur Naugachhia, TelghiKharik, Kairiyan, Khalgaon, Dharhara, Gopalpur. Trial was designed in randomised block design. During Trial every stage of development monitored critically. Data were collected on plant height, stem girth, weight of fruit, weight of hand, weight of bunch, yield and economics. All collected data subjected for statistical analysis.

\section{Results and Discussion}

This on farm trial "Standardization of nutrional requirement of Banana over conventional Method for quality yield of Banana (Musa paradiscica). Banana is the most remunerative and popular fruit crop in the world. To work for enhancement of quality of banana is our responsibility. Banana is a heavy feeder crop. Application of fertilizer and specific products should be coordinated with the the plant cycle round the year. Obviously, it should be applied at fast growing stage. Research also shows that an average ton of banana removes $8 \mathrm{~kg} \mathrm{~N}, 1.5 \mathrm{~kg}$ Phosphorus and 25kg K (potash) (Mr Guy Selo, 1918; Willemse et al., 2008). Post - analysis of soil also indicate that removal of potash higher than the rest element. Banana cultivation Guide (2013) also advocated the importance of potash and suggested use the fertilizer in the ratio $3: 1: 6$ nitrogen, phosphorus, potassium. It also visible from different treatments the technology option 1(urea $400 \mathrm{~g}+\mathrm{DAP} \quad 100 \mathrm{~g}+700 \mathrm{~g}$ MOP + vemicompost) where potash dose is higher. In this treatment highest yield that is 67.89 tons per hectare obtained. This is due to the fact that potassium plays a major role starch and protein synthesis. So, make it key element in its cultivation. Potash also helps in cold management in banana and provides disease resistance. (Banana Expert System, TNAU). Higher dose of nitrogen also helps in better photosynthetic rate. Higher potash consumption by banana is also justified by work of IPNI (china.ipni.net) The second highest yield that is 63.14 tons per hectare obtained in T2 (urea 400g +DAP $100 \mathrm{~g}+300 \mathrm{~g}$ $\mathrm{MOP}+$ vermicompost). This shows that higher dose of fertilizer is required during period of 
high growth. Suitable dose of nitrogen at appropriate time of application play a significant role in increasing yield. Nitrogen is the chief promoter of growth. It induces vegetative growth create strong green structure that is essential for higher yield (www.ikisan.com). So far as we are concern
DAP dose is almost similar in all treatments. So, higher dose of DAP used by farmers in place of potash is merely waste of money that increasing the cultivation cost. High cost of cultivation of farmers practice due to high rate of DAP fixed by Government (Table 2 and 3).

Table.1 Status of soil

\begin{tabular}{|l|l|l|l|l|l|}
\hline Soil test & pH & EC & OC & P2 O5 & K2O \\
\hline Pre -Planting & 6.38 & 0.45 & 0.51 & 40.3 & 155 \\
\hline Post - planting & 6.20 & 0.43 & 0.50 & 41.2 & 142 \\
\hline
\end{tabular}

Table.2 Performance of technology with performance indicators

\begin{tabular}{|l|l|l|l|l|l|l|}
\hline $\begin{array}{l}\text { Technology } \\
\text { option }\end{array}$ & $\begin{array}{l}\text { Plant } \\
\text { height(cm) }\end{array}$ & $\begin{array}{l}\text { Stem girth } \\
\text { (cm) }\end{array}$ & $\begin{array}{l}\text { Weight of } \\
\text { hand (kg) }\end{array}$ & $\begin{array}{l}\text { Weight of } \\
\text { bunch(kg) }\end{array}$ & Yield(ton) & BC ratio \\
\hline $\begin{array}{l}\text { Farmers } \\
\text { practice }\end{array}$ & 173 & 42.75 & 1.40 & 15.40 & 47.52 & 2.50 \\
\hline T1 & 190.8 & 46.10 & 2.0 & 22.00 & 67.89 & 3.30 \\
\hline T2 & 188.8 & 45.10 & 1.86 & 20.46 & 63.14 & 2.90 \\
\hline T3 & 174 & 43.10 & 1.76 & 19.36 & 59.74 & 2.80 \\
\hline
\end{tabular}

Table.3 Three treatments which were considered with farmers practice

\begin{tabular}{|l|l|l|}
\hline S.No. & Technology option & Treatments \\
\hline $\mathbf{1}$ & Farmer's practice & $\begin{array}{l}\text { 500g urea+400gDAP+150g } \\
\text { MOP per pseudostem } \\
\text { random application }\end{array}$ \\
\hline $\mathbf{2}$ & Technology option -1 & $\begin{array}{l}\text { Urea 400g+DAP 100g +700g } \\
\text { MOP+500g vermicompost } \\
\text { per peudostem at 30DAT, } \\
\text { 75DAT135 DAT, 170DAT, } \\
\text { 225 DAT\&270DAT }\end{array}$ \\
\hline $\mathbf{3}$ & Technology option- 2 & $\begin{array}{l}\text { Urea 400g +DAP 100g+300g } \\
\text { MOP followed same DAT }\end{array}$ \\
\hline $\mathbf{4}$ & Technology option -3 & $\begin{array}{l}\text { Urea 300g+200g DAP+150g } \\
\text { MOP+500g vermicompost } \\
\text { per peudostem applied at } \\
\text { 0DAT, 45 DAT, 90 DAT, } \\
\text { 150 DAT, 200 DAT \& at the } \\
\text { time of flowering }\end{array}$ \\
\hline
\end{tabular}


Table 3 also shows the effect of increased dose of potash and nitrogen. Higher dose of phosphorus is not required by banana because it has its own support system to supply phosphorus if required by the plant.

In very initial stage of growth high phosphorus is utilized which is helpful in developing strong root system. This strong root system helps in absorption of other nutrients.

Banana is an important crop for growers. Nation-wide its improvement is necessity. This can be achieved by proper fertilizer management and disease management. Both aspects play a vital role in qualitative yield of banana with high $\mathrm{BC}$ ratio.

We have observed in technology option 1 that is urea $400 \mathrm{~g}+100 \mathrm{~g} \mathrm{DAP}+700 \mathrm{~g}$ MOP per pseudostem per year at five split doses at 30 DAT, 75 DAT, 135 DAT, 225 DAT and 270 DAT gave the best result 67.89 tons with ratio 3.3. This indicates that higher dose of potash is basic requirement for qualitative yield of banana. This result was justified by other worker.

\section{References}

Horticulture Statistics at a glance 2017 published by Government of India, Ministry of Agriculture.

http://www.banana planters.com/ Banana cultivation Guide (2013)ss

Mr Guy Selo (1918) Banana Fertilizer Management, CEO of Smart Fertilizer Management Software And International expert in Plant Nutrition and irrigation.

nhb.gov.in/report

files/banana/banana.htm(2017)

Willemse, W. and Kwa Zulu Natal (2008)

Banana Production compiled by Directrote of Agriculture. Text revised by Institute of Tropical and SubTropical crops South Africa.

WWW.agritech. Tnau.ac.in

www.ikisaan.com Banana Nutrient Management.

\section{How to cite this article:}

Mamta Kumari and Singh, R.N. 2019. Standardization of Fertilizers in Banana (Musa paradiscica) for Better Growth and Yield. Int.J.Curr.Microbiol.App.Sci. 8(07): 2478-2482. doi: https://doi.org/10.20546/ijcmas.2019.807.305 